DOI: 10.46340/ephd.2020.6.3.9

Liudmyla Gutsalo, PhD in History

ORCID ID: https://orcid.org/0000-0002-2627-3520

Galyna Mishchuk, PhD in History

ORCID ID: https://orcid.org/0000-0003-1239-330X

Zhytomyr Ivan Franko State University

\title{
CONTRIBUTION OF PROTOIEREUS MYKOLA TRYPOLSKY TO THE STUDY OF VOLYN HISTORY
}

\author{
Людмила Гуцало, к. і. н. \\ Галина Міщук, к. і. н. \\ Житомирський державний університет імені Івана Франка, Україна

\section{ВНЕСОК ПРОТОІЕРЕЯ МИКОЛИ ТРИПОЛЬСЬКОГО У ВИВЧЕННЯ ІСТОРІЇ ВОЛИНІ}

19th century is known not only by the formation of an intellectual stratum of spiritual origin but also by the appearance and active development of local lore interest within the circle of spiritual intelligentsia. The article collects and analyzes the Volyn period of life and creative path of the priest, local historian and active researcher of the history of Volyn - Mykola Trypolsky (18471911). During his church and pedagogical practice in Zhytomyr, he was actively engaged in the study of Volyn antiquity. The article is focused on the fact that the detailed study of Volyn was his basic educational work. The article covers the participation of Mykola Trypolsky in the Volyn Church-Archaeological Society - the Society of Researchers of Volyn. Also, the article contains an overview of the main printed publications published in the "Volyn Diocesan Gazette", "Volyn Historical and Archaeological Collection". These publications took on the responsibilities of developing regional research and organizing the local history movement.

Keywords: Volyn Diocesan "Brotherhood", Church-Archaeological Society, the magazines "Volyn Diocesan Gazette", "Volyn Manuscript Gospel of the XVI century", "Historical information about the Zhytomyr city, Volyn Province".

Сучасні суспільні трансформації надзвичайно посилили інтерес до традицій українського духовного просвітництва, до набутого впродовж століть знання. Актуальним завданням сьогоднішньої історичної науки залишається всебічне вивчення культурно-просвітницьких постатей, чиї імена перебували поза межами наукових зацікавлень, зокрема церковних діячів XIX століття, які були активними учасниками не лише релігійного, а й громадського та культурно-наукового життя. Серед священнослужителів було багато яскравих особистостей, які брали участь в археологічних, етнографічних експедиціях, працювали в архівах, досліджували документи, весь вільний час займалися вивченням свого краю, формуючи потужну когорту краєзнавців. Для XIX ст. це було цілком звичним і закономірним явищем, що визначалося соціальним статусом священика. У віданні священиків знаходилися церковні архіви, вони вели метричні та сповідні книжки, складали клірові відомості. Все це дозволяло їм більш грунтовно і вільно орієнтуватися в історичних процесах. Неабияку роль у формуванні масової історичної свідомості серед служителів культу відігравала спрямованість системи духовної освіти в семінаріях й академіях, де формувалися працездатність, сумлінність, наполегливість, порядність та інші важливі риси, які в подальшому значно допомагали в дослідницький роботі.

Постать протоієрея Миколи Миколайовича Трипольського є малознаною, його багатогранна діяльність не знайшла належного висвітлення у вітчизняній історіографії. Теоретичні засади нашого дослідження склали концептуальні ідеї С. Жилюка, Ю. Хитровської, Ю. Коптюха, 
Б. Бойка ${ }^{1}$. Їхні праці присвячені православному духовенству Волинської губернії. Окремі аспекти теми, які характеризують діяльність місцевих церковних братств Волині, відображено в роботах С. Гаврилюк, І. Тимочко ${ }^{2}$. Роль Миколи Трипольського як краєзнавця та дослідника Волині означена в роботі М. Костриці та Р. Кондратюка ${ }^{3}$. У науковому обігу є також розпорошені дослідження, де ім'я Миколи Трипольського пов'язують з Волинським і Пересопницьким Свангеліями ${ }^{4}$.

Джерельною базою дослідження виступає комплекс праць, пастирських послань, повчань протоієрея М. Трипольського. Основним джерелом стали його публікації в часописі «Волынские епархиальные ведомости» (далі- ВЕВ) та збірнику «Волынского историко-археологического сборника» (ВИАС).

Метою статті є дослідження постаті протоієрея Миколи Миколайовича Трипольського, його громадсько-просвітницької та краєзнавчо-дослідницької діяльності, а також ролі його наукової спадщини в дослідженні історії Волині на основі аналізу опублікованих матеріалів й архівних джерел.

Микола Миколайович Трипольський присвятив все своє життя церковному служінню. Основні біографічні дані про М. Трипольського містить некролог, надрукований у розділі «Хроніка» офіційної частини $\mathrm{BEB}^{5}$. Народився в 1847 р., навчався у Києво-Подільському духовному училищі, далі в Київський семінарії. Випускник Київської академії 1869 р., курс XXV (1865-1869рр.). Після закінчення академічного курсу в 1871 р. був направлений в Одеську духовну семінарію викладачем гомілетики, літургіки та практичного керівництва для пастирів. У 1872 р. за власним проханням був переведений у Київську духовну семінарію викладачем тих же дисциплін, а в 1873 p. став кореспондентом церковно-археологічного товариства при Київський духовній академії. Також він був висвячений у священики св. Сергіївської гімназії, де і викладав. Згодом призначений учителем Закону Божого церкви при Житомирській чоловічій гімназії, де лишався до 1884 p. 31877 р. викладає Закон Божий у колишній прогімназії, яку перетворено в 2-гу чоловічу гімназію, де працював до 1896 р. Упродовж 1881-1884 pp. М. Трипольський був благочинним міського округу. 31884 р. обіймав посаду ключаря кафедрального собору. Потім був благочинним жіночого духовного училища, нетривалий період - законовчителем у старших класах Маріїнської жіночої гімназії. У 1890 р. його призначено кафедральним протоієреєм та благочинним кафедрального собору, членом духовної консисторії. На цій посаді лишався до 1903 р. Крім того, він був членом єпархіальної опікунської ради та цензором проповідей. У наступні роки протоієрей був попечителем Крошенської церковноприходської школи, почесним членом єпархіальної училищної ради та благочинним домових церков 1-ї та 2-ї гімназії, богоугодних закладів міста та тюремної фортеці. 31908 р. знову викладав Закон Божий у 2-й чоловічій гімназії. Входив до розпорядчого комітету Руської публічної бібліотеки, був гласним членом Міської Думи.

За сумлінну службу М. Трипольський отримав низку нагород: 1875 р. - скуфію та грошову нагороду, 1879 р. - камилавку, 1882 р. - наперсний хрест, 1890 р. - золотий кабінетний хрест 3 дорогоцінним камінням. Окрім перерахованих нагород, був нагороджений орденом св. Анни 2-го ступеня та св. Володимира 4-го ступеня (у 1897 р. за службу по єпархіальному відомству) та полицею.

\footnotetext{
${ }^{1}$ Жилюк, С. (1996). Російська православна цеерква на Волині (1793-1917 рр.). Житомир: Журфонд, 174. Хитровська, Ю. (2001). Громадянсько-політична позиція духовенства Правобережної України наприкінці ХVIIIсередині XIX cm. (в контексті иерковної політики самодержавства): автореферат дисертації на здобуття наукового ступеню кандидата історичних наук. Київ: Інститут філософії ім. Г. С. Сковороди НАН України, 19; Коптюх, Ю. (2005). Реформи устрою Російської Православної иеркви в Правобережній Україні (кінець XVIII перша половина XIX cm.): автореферат дисертації на здобуття наукового ступеню кандидата історичних наук. Київ: КНУТШ; Жилюк, С., Бойко, Б. (2010). Релігійна політика цุаризму на Волині (1793-1917 рр.). Острог: Острозька академія, 228.

${ }^{2}$ Гаврилюк, С. (1997). Діяльність православних церковних братств Волині у ХІХ столітті. Науковий вісник Волинського державного університету ім. Лесі Українки: Історія, 2, 40-42; Тимочко, I. (2010). Організаційні засади діяльності православних братств Волинської губернії. Нова педагогічна думка, 3, 10-13.

${ }^{3}$ Костриця, М., Кондратюк, Р. (1996). Краєзнавець М. Трипольський і його нарис про Житомир. Житомирський вісник. (9 липня).

${ }^{4}$ Міщук, С. М. (2009). Збирання та наукове описування рукописно-книжкової спадщини Украӥни (друга половина XIX-30-ті роки XX ст.). Киев: Полісся, 284-286.

${ }^{5}$ Вольнские епархиальные ведомости (1911) 11 (10 мая), 249.
} 
Дані про родину М. Трипольського уривчасті. Дружина - Марія Ієронимівна (1857-08.05.1913)1 . У метричній книзі Державного архіву Житомирської області зберігся запис, що 30 квітня 1906 р. у Преображенському соборі вінчались сотник 2-ї Донської Козачої батареї Володимир Семенович Семенов та дочка кафедрального протоієрея Лідія, 22 років. Поручителем нареченого був колезький асесор Микола Миколайович Трипольський ${ }^{2} 3$ архівних документів відомо, що один із синів священика - Олександр Миколайович - був судовим слідчим ${ }^{3}$.

Основним проявом громадської діяльності М. Трипольського була його участь у роботі різних товариств. Він був членом Імператорського Православного Палестинського Товариства (ІППТ), що займалося просвітницькою діяльністю, друкувало науково-популярні видання, зокрема читання про Святу Землю, тексти яких використовувалися як для самостійного читання, так і для проведення в Єрусалимі й у відділах ІППТ по всій Російській імперії «палестинських» читань для народу. Готові тексти організатори читань використовували для лекцій, які проводилися в супроводі «туманних картин» для «чарівного ліхтаря», скляні пластини для яких можна було придбати в ІППТ. Іноді в рамках палестинських читань влаштовувалися концерти духовних та народних пісень. Для складання текстів Товариство залучало відомих церковних діячів, серед яких був настоятель Преображенського кафедрального собору в Житомирі Волинської єпархії, краєзнавець, церковний історик, протоієрей Микола Миколайович Трипольський, авторству якого належить тема 47-го читання «Віфлеєм і його околиці» ${ }^{4}$.

Першою друкованою працею М. Трипольського стала його дисертаційна робота на здобуття ступеня магістра богослов’я «Уніатський митрополит Іпатій Потій та його проповідницька діяльність» $(1878 \text { р. })^{5}$. Це була одна 3 перших наукових розвідок, присвячених постаті митрополита, що виступав серед головних супротивників Віленського братства. У своєму дослідженні М. Трипольський представив загальний нарис біографії Іпатія Потія, зовнішній склад і внутрішній характер його проповідей. Особлива увага була приділена вивченню діяльності уніатського митрополита в справі ревного просування церковної унії. Автор досить докладно описує всі утиски й образи, що наносяться Іпатієм Свято-духовному братству. Заслуга дослідника полягає ще й у тому, що він використав велику кількість документів, пов'язаних 3 історією унії в Україні та Білорусі. Окремим аспектом М. Трипольський розглянув уніатське суспільство як реальність тогочасного суспільно-релігійного життя волинського регіону. Відмічаємо, що ця робота $\epsilon$ чи не єдиною спробою православно орієнтованого дослідника об'єктивно осмислити духовну спадщину ініціатора Берестейської унії.

Важливою віхою біографії М. Трипольського $є$ той факт, що він був членом Житомирського Свято-Володимиро-Василівського братства (офіційна назва- Волинське єпархіальне), яке було головним серед місцевих церковних братств на Волині. Офіційне відкриття братства при кафедральному соборі відбулось 6 серпня 1888 р. на честь дев’ятсотліття хрещення Русі. Головною метою братства було «просвітити світлом істинного християнського вчення людей невіруючих, сприяти спрямуванню на правий шлях тих, хто ухилився від єдності з істинною канонічною церквою (євреїв, штундистів, розкольників, чехів)», та сприяти поширенню православ'я серед «іновірців і осіб інших віросповідань» ${ }^{6}$ Для цього організовувались не тільки в Житомирі, а й по всій Волинський єпархії поза офіційною церковною службою читання та бесіди на теми християнської моралі. Ще однією функцією братства було збирання та збереження церковно-археологічних пам'яток Волинської єпархії. Планувалося влаштувати при Житомирському книжковому складі єпархіальну бібліотеку та сприяти відкриттю бібліотек в інших повітових містах, парафіях, де були поширені різні секти.

Уся робота братства здійснювалася на основі затвердженого статуту й підпорядковувалась архієпископу Волинському і Житомирському Паладію. За статутом, братство мало організовану структуру, а ії членами могли бути люди будь-якого стану та звання, поділяючись на почесних i дійсних. 3 метою контролю щорічно друкувались звіти про проведену роботу. 3 проповідницькою

\footnotetext{
${ }^{1}$ Державний архів Житомирської області (далі - ДАЖО), ф.1, on.77, cnp. 1782.

2 ДАЖО, ф.1, on.77, сnр. 1799.

3 ДАЖО, ф..24, on.1, сnр. 242.

${ }^{4}$ Указатель трудов Императорского Православного Палестинского Общества 1881-2007 (2009). Петербург, 284-290.

5 Трипольский, Н. (1878). Униатский митрополит Ипатий Поцей и его проповедническая деятельность. Киев: Типография В. Давиденко, 298.

${ }^{6}$ Вольнь: Исторические судьбы Юго-Западного края (1888). Сост. Н. И. Петров. Санкт-Петербург:

Общественная польза, 200.
} 
метою для місцевого населення члени братства організовували безкоштовні, поза церковною службою, релігійно-моральні читання. Читання проводили щосуботи після вечірньої літургії в кафедральному соборі м. Житомира ${ }^{1}$ Народні читання відбувалися під керівництвом члена ради братства протоієрея М. Трипольського та священика М. Щеглова у приміщенні міської думи або Житомирського духовного чоловічого училища ${ }^{2}$. Протягом 1890-1891 pp. братство провело 16 читань. Житомирські братчики збиралися запровадити безкоштовні релігійно-моральні читання i в інших містах єпархії.

Крім того, Микола Миколайович входив до Волинського губернського статистичного комітету, а 31894 р. став членом розпорядчого комітету Волинського Церковно-археологічного товариства (ВЦАТ).

За статутом ВЦАТ передбачалося видання власного щорічника наукових праць, у якому поряд із друком статей, які висвітлюють минуле Волині, намагатися друкувати нові маловідомі матеріали як науковців, так і любителів старовини, багато з яких належали до духовенства Волині. Саме на останніх, головним чином, і був розрахований збірник.

Перший том «Волынского историко-археологического сборника» вийшов друком у 1896 р. У передмові зазначено, що в його складанні брали участь М. Трипольський, Г. Крижановський, О. Фотинський. До цього тому увійшли матеріали про історію створення ВЦАТ, його статут та списки членів товариства, звіт про роботу в 1894-1895 pp., промова на урочистому відкритті товариства архієпископа Модеста.

Згаданий вище збірник уміщував три статті Миколи Трипольського. Перша- «Сказание о чудотворной иконе Божей Матери Дерманской и песни в честь ея», написана на основі польського рукопису XVIII ст. «Informacya о Obrazie Matki Nayswietszey darowanym Iego Mosci Xiedzu Alexandrowi Iodce, Opatowi Dermanskiemu, Dubienskiemu I S-Krzyzskiemu od W. Iey Mosci Pani Katarzyny z Izdebskich Borzobohatowey Podczaszyney Braclawskiej uniecznorodzonej siostry tegoz Iego Mosci Xiedza Opata, podana w Roku 176318 S-bris». Переклад й обробка тексту М. Трипольського. Статті містили свідчення явлення ікони, опис зцілень і дві пісні, що прославляють Богородицю, уривок Монастирського літопису про «чудеса зцілення, вигнання бісів».

Автор, аналізуючи пісні на честь ікони Божої Матері Дерманської, висуває припущення, що в Дерманському монастирі були дві благодатні ікони Богоматері. Він відмітив, що перша пісня написана місцевою мовою (українською - Авт.), але польськими буквами, друга - польською. Вивчаючи їх, дослідник робить висновок, що автори цих пісень - різні. Також Микола Миколайович зазначив, що про другу ікону автор польської пісні говорить, що вона прибула з Литви та «явила чудеса» в Дерманській пустелі декілька сотень років тому. Він зазначає, що в церкві Дерманського чоловічого монастиря $\epsilon$ ікона, про яку пише польський рукопис «Благодатная икона Пресвятой Богородицы Казанской весьма древний образ». Не заперечуючи важливості та значення ікони, про яку йде мова в польському рукописі, М. Трипольський вказує, що в Дермані існує більш давня ікона, про яку в Дерманському монастирському описі (від 9 січня 1776 р.) йдеться, що вона $з$ незапам'ятних часів відома своїми чудесами. На доказ цього в монастирському «Помяннику» поряд 3 іменем духівника ієромонаха Авраамія зазначено: «Се аз приидох слепым до Дерманя, и прозрех у Святой Пречистой образу року 1636 июня 1-го» ${ }^{3}$.

Наступна стаття М. Трипольського - «Дерманский архимандрит Мелетий Смотрицкий, его сочинения и надгробная надпись на его могиле в Дермани» ${ }^{4}$ У ній автор висвітлює біографію М. Смотрицького, відмічає, що на його батька, Герасима Смотрицького, звернув увагу Костянтин Острозький і запросив очолити школу (згодом заклад став слов'яно-греко-латинським колегіумом). У 1581 р. Г. Смотрицький брав дієву участь у виданні Острозької Біблії. Перед першою передмовою до Біблії, на звороті титульного аркуша, розміщено зображення герба Василя-Костянтина Острозького та вірш-присвята, звернення до князя «Зри сія знаменія...», автором якого був Герасим Смотрицький. Далі М. Трипольський писав, що «Мелетій Смотрицький довго працював над

\footnotetext{
1 Там само, 202.

2 Девятисотлетие православия на Вольни 992-1892 г2. (1892). Житомир: Тип. Литорг. Е. П. Льва, 202.

3 Трипольский, Н. ( 1900). Сказание о чудотворной иконе Божей Матери Дерманской и песни в честь ея. Волынский историко-археологический сборник. Житомир, (Вып. 1), 1-14. («Праці» у т. 1. ВИАС в «компакті», без нумераціi).

4 Трипольский, Н. (1900). Дерманский архимандрит Мелетий Смотрицкий, его сочинения и надгробная надпись на его могиле в Дермани. Житомир, (Вып. 1), 1-7.
} 
складанням граматики грецької мови й видав таку в 1615 р. під заголовком «Institutionum iinguae graecae libri duo».

Третя стаття дослідника мала назву «Документы относящиеся к древней истории православного Почаевского монастыря на Волыни» ${ }^{1}$. Це п'ять розрізнених документів початку XV ст., власника яких M. Трипольський не називає. У першому документі без заголовку йдеться про те, що під час епідемії в Почаївському монастирі ієромонаху Модесту явилась Богородиця зі словами: якщо виправиться життя монастирської братії - хвороба відступить. Другий, теж без назви, присвячений поселенню на Почаївський горі 1240 р. Дослідник визнає, що доказів про заснування поселення недостатньо, й давня історія Почаївського монастиря мало досліджена. Третій документ - пісня на честь Мефодія Почаївського. Четвертий - «Дыпломат» є дарчою від 11 лютого 1213 р. Михайла Центера та його дружини Олени Центер на вічне володіння монастирем їхніми угіддями й усіма прибутками з них.

Документи складені слов'янською мовою, в чудовому стані, гарно збережені. М. Трипольський зазначає, що написані вони правильним полууставом. Аркуші пронумеровані римськими літерами. Священик висловлює припущення що це сторінки рукописної книги «Памятник монастиря Почаевского», яка втрачена, і сподівався знайти ще рукописи та відновити цю пам'ятку. Крім того, він припускав, що п’ятий, найбільший із текстів, представлений як польський базиліанський рукопис «MONASTYP SKIT» 1732 р., є також частиною книги «Памятник монастиря Почаевского». Цей рукопис знайомить з давньою історією Почаївського монастиря, вказує, що монастир заснував православний грек Мефодій.

Ми розкриваємо ці публікації, так, як писав про них М. Трипольський, з незначними сумнівами в їх достовірності.

Одразу після виходу збірника, в 1896 р. на його публікації з’явилися критичні відгуки. Один із них дала Санкт-Петербурзька газета «Новое Время» 1896 р. № 7466. Інші - це статті у журналі «Киевская старина» за підписом «Волинець» (псевдонімом історика Ореста Левицького). Перша «Новыя открытія въ области древневолынского бытописанія» ${ }^{2}$, друга -« Почадъвская летопись. (Новейшее произведение древне-волынской письменности» $(1898 \text { р.) })^{3}$. О. Левицький зазначив, що, всупереч правилам видання нововідкритих письмових історичних джерел, М. Трипольський не вказав імені власника документів. Іронічно, але з повагою до особи Миколи Миколайовича, він пише «...неолетописець таинственно показал их о. Трипольскому и, должно быть, сочинил при этом какуюнибудь необыкновенную легенду относительно их приобретения. Иначе трудно понять, каким образом почтенный протоиерей, без сомнения, читавший на своем веку древние летописи, мог впасть в такое невероятное ослепление, что принял за подлинную древность самую грубую, бездарную и невежественную фальсификацию» ${ }^{4}$. На думку О. Левицького, Миколу Трипольського ввів в оману «безграмотний фальсифікатор», вважаючи, що основною причиною таких підробок була «патриотическая любовь к истории»

Сумна історія публікацій священика i рецензій О. Левицького знайшла відображення в мемуарах професора Київської духовної академії Миколи Петрова.

За зовнішньою та внутрішньою формою документа, вірогідністю його змісту, текстологічним аналізом М. Трипольський міг би встановити його оригінальність або підробку. Але, на наш погляд, у бажанні бачити такий давній літопис священик переміг над науковцем.

У другому випуску «Волынского историко-археологического сборника» М. Трипольський публікує своє кодикологічне дослідження Волинського Євангелія ${ }^{6}$. Він володів примірником рукописного Євангелія 1571 p. і назвав його Волинським. Цей рукопис належав протоієрею, настоятелю Володимирського Миколаєво-Успенського собору Севастіану Коссовичу, потім - його

\footnotetext{
${ }^{1}$ Трипольский, Н. (1900). Документы относящиеся к древней истории православного Почаевского монастыря на Волыни. Житомир, (Вып. 1), 1-9.

${ }^{2}$ Волынец. (1896). Новые открытия в области древлеволынского бытописания. Киевская Старина, Киев:

Тип. Г. Т. Корчак-Новицкого, 93-109.

${ }^{3}$ Волынец. (1898). Почадъвская летопись (Новейшее произведение древне-волынской письменности).

Киевская Старина, Киев: Тип. Г. Т. Корчак-Новицкого, 87-106.

${ }^{4}$ Волынец. (1898). Почадъвская летопись (Новейшее произведение древне-волынской письменности).

Киевская Старина, Киев: Тип. Г. Т. Корчак-Новицкого, 90.

${ }^{5}$ Волынец. (1897). Два поддельных исторических документа. Киевская Старина, Киев: Тип. Г. Т. КорчакНовицкого, 442.

6 Трипольский, Н. (1900). Волынское рукописное Евангелие XVI ст. Вольнский историко-археологический сборник, Житомир, 2, 1-114.
} 
сину Свграфу Коссовичу, який в 60-х роках XIX ст. був учителем Житомирської чоловічої гімназії. Після смерті останнього потрапив до житомирських евреїв-лахмітників. М. Трипольський описав та проаналізував цей рукопис, опублікував фрагменти тексту, порівнявши його 3 текстом Пересопницького Євангелія 1556-1561рр., та дійшов висновку, що Євангеліє 1571 р. є списком останнього. Дослідник виділив особливості Волинського Євангелія: знаки пунктуації, скорочення слів i, внаслідок цього, винесення деяких букв наверх рядків, різні прикраси при зображенні євангелістів, віньєток, заставок; порівняв каліграфічну обробку рукопису.

Цінність Свангелія 1571 р. першим відмітив П. Житецький ${ }^{1}$. О. Назаревський, перебуваючи в Житомирі разом із семінарієм В. Перетца, ознайомився з цим рукописом ${ }^{2}$. Він підкреслює, що, крім цього Євангелія, у М. Трипольського був цінний примірник Острозької Біблії 1581 р., який мав багато приписок, котрі він підготував до друку та планував видати. Волинські рукописні Євангелія та Апостоли були об'єктом уваги Г. Бугославського, який робив доповідь на IX археологічному з'їзді у Вільно в 1893 р., роблячи акцент на «Пересопницькому Євангелії» 1556-1561 рр. та Євангелії М. Трипольського, їх специфічній мові, характерним зовнішнім особливостям ${ }^{3}$. На думку знаного книгознавця Л. Дубровіної, Волинське Євангеліє 1571 р. (доля книги після революції 1917 р. невідома) було близьким по тексту й оформленню до Пересопницького. Вважається, що ця книга була списком з Пересопницького Свангелія.

Друга значна праця М. Трипольського в збірнику- «Исторические сведения о городе Житомире, Волынской губернии» ${ }^{4}$, у якій він систематизував наукові та краєзнавчі публікації. Краєзнавець не описував детально історію міста, а згрупував у логічній послідовності та виклав окремі розпорошені до цього відомості. Використовуючи велику кількість джерел, посилаючись на праці таких дослідників, як Ю. Крашевський, М. Теодорович, А. Братчиков, І. Петров та інші, він аналізує різні версії походження назви міста, часу забудови. Висвітлюючи історію міста, автор посилається на документи Київського архіву. У висновках робить помітку, що буде задоволеним, якщо цей матеріал послужить для серйозної праці в цій галузі.

Ця робота також отримала критичний відгук Ореста Левицького ${ }^{5}$. У розділі «Бібліографія» часопису «Киевская старина» було розміщено рецензію на другий збірник ВЦАС, де поряд зі схвальним відгуком на дослідження Волинського Євангелія містилися критичні зауваження до праці «Исторические сведения о городе Житомире, Волынской губернии». Критик зауважував, що автор використав старі польські рукописи й не врахував сучасні польські й російські дослідження, нарікав, що частина дослідження далека від повноти, містяться помилки, зокрема неповний список намісників і старост міста. Водночас Левицький підкреслює важливість опису Житомира першої половини XIX ст., зазначаючи, що це найбільш цінна частина статті. Варто відмітити, що такі критичні зауваження були звичною нормою того часу й направлені на подальші дослідження. О. Левицький зазначає: «Отъ ошибки никто не гарантированъ. Такъ что ложный стыдъ, можно и отбросить» ${ }^{6}$

Окрім публіцистичної роботи, члени ВЦАТ займалися пошуками матеріалів в археографічних експедиціях, наукових відрядженнях. За завданням історика В. Антоновича впродовж 1897-1899 pр. М. Трипольський спільно з О. Фотинським здійснили чимало наукових подорожей Волинню. Зокрема, до Городищенського, Дерманського, Загоровського, Корецького, Любарського, Тригірського монастирів, м. Овруч. Зібрані ними матеріали В. Антонович використав у своїй фундаментальній праці «Археологическая карта Волынской губернии». За результатами обстеження М. Трипольським i О. Фотинським пам'яток Овруча невдовзі на урядовому рівні було прийнято рішення про реставрацію унікальної пам’ятки архітектури Київської Русі - Свято-Василівської церкви ${ }^{8}$.

\footnotetext{
${ }^{1}$ Житецький, П. (1876). Описание Пересопницкой рукописи XVI cm. с приложеним текста Евангелия от Луки, выдержек из других евангелистов и 4-х странии снимков. Киев, (79), 4.

2 Занятия профессорского стипендиата А. Назаревского. Перетц, В. (1911). Отчет об экскурсии семинария русской филологии в Житомир 21-26 октября 1910 года. Киев, 47-51.

${ }_{3}^{3}$ Міщук, С. М. (2009). Збирання та наукове описування рукописно-книжкової спадщини Украйни (друга половина XIX-30-ті роки XX ст.). Київ, 285.

4 Трипольский, Н. (1900). Исторические сведения о городе Житомире, Волынской губернии. Вольнский историко-археологический сборник. Житомир, (Вып. 2), 49-116.

${ }^{5}$ Киевская Старина (1901). (Том LXXV). Киев: Тип. Г. Т. Корчак-Новицкого, 95-109.

6 Левицкий, Ор. (1896). Археологический съезд в Риге. Киевская Старина, Киев: Тип. Г. Т. Корчак-Новицкого, 49.

${ }^{7}$ Антонович, В. Б. (1900). Археологическая карта Вольнской губернии. Москва: Тип. Г. Лисснера и А. Гешеля, (V), 130.

${ }^{8}$ Костриця, М., Кондратюк, Р. Краєзнавець М. Трипольський і його нарис про Житомир. Житомирський вісник. (1996, 19 липня).
} 
Одночасно з заснуванням ВЦАТ було отримано наказ Святійшого Синоду з дозволом на відкриття Волинського єпархіального давньосховища (ВЄД), функцією якого мало бути зосередження цінних предметів та пам'яток старовини, що перебували у церквах, монастирях, приватних зібраннях священиків. Одразу після відкриття давньосховища при архієрейському дворі його організаторам стало зрозуміло, що приміщення не відповідає музейним вимогам. Тому Церковно-археологічне товариство в 1894 р. розпочало спорудження власного будинку під музей і бібліотеку на Вільській вулиці, на ділянці, що належала Преображенському кафедральному собору. Керував цим будівництвом протоієрей М. Трипольський. Приміщення площею 224 кв. сажень (більше $1000 \mathrm{~m}^{2}$ ) - 3 великою залою (близько $240 \mathrm{~m}^{2}$ ) із сферичною стелею, чотирма кімнатами для бібліотеки і чотирма для завідуючого давньосховищем. До серпня 1896 р. тут вже планували розмістити колекцію, але через нестачу коштів недобудований будинок були змушені передати в оренду Товариству опікунства про народну тверезість і Народній чайній. Лише на початку XX ст. ВЄД переїхало до власного приміщення.

У 1900 р. М. Трипольський стає членом Товариства дослідників Волині ${ }^{1}$, яке об'єднало місцеву інтелігенцію, зацікавлену своїм краєм, до пробудження та поширення інтересу до історичних знань, до процесів, що відбуваються узв'язку зі змінами в політичному та культурному житті, досягненнями у природничих науках. Микола Миколайович у Товаристві очолював секцію історичних наук (історія політична та побутова, архівознавство, археологія, археографія, палеографія, нумізматика, геральдика), до складу якої входило 30 осіб. Через рік він від головування в секції самоусунувся.

Указом Сенату від 17 лютого 1906 р. М. Трипольського за вірну службу та здобутки на просвітницькій ниві було затверджено в дворянській гідностіі

Тяжка хвороба нирок не дозволила Миколі Миколайовичу активно займатися громадською діяльністю, але свою діяльність як священика та викладача він продовжував до смерті. Помер М. Трипольський 4 березня 1911 р., похований на Вільському (Руському) кладовищі в м. Житомирі.

Становлення волинського краєзнавства в другій половині XIX - на початку XX ст. відбувалося в умовах, коли регіон перебував у складі Російської імперії. Закономірно, що на цілі, завдання і зміст тогочасних досліджень значно впливала панівна імперська ідеологія. Сьогодні можна говорити, що праці Миколи Трипольського, які були написані з проімперських позицій, мають певні помилки та недоліки. Але вони містять значний фактичний матеріал, тому не втрачають актуальності та викликають науковий дослідницький інтерес і по сьогодні. Микола Миколайович Трипольський був одним з тих, хто закладав міцний фундамент для розвитку краєзнавчих досліджень в Україні, цікавою та неординарною особистістю. У цілому історико-краєзнавчі дослідження волинських священиків $€$ маловивченою темою в український історії.

\section{References:}

1. Antonovich, V. B. (1900). Arkheologicheskaya karta Volynskoy gubernii [Archaeological map of the Volyn province]. Moscow: Tip. G. Lissnera i A. Geshelya. [in Russian].

2. Volynets. (1896). Novye otkrytiya v oblasti drevlevolynskogo bytopisaniya [New discoveries in the field of ancient Volyn writing]. Kievskaya Starina [Kyiv Olden], Tom LV. Kyiv: Tip.G.T.Korchak-Novitskogo. [in Russian].

3. Volynets. (1897). Dva poddelnykh istoricheskikh dokumenta [Two fake historical documents]. Kievskaya Starina [Kyiv Olden], Tom XVI. Kyiv: Tip.G.T.Korchak-Novitskogo. [in Russian].

4. Volynets. (1898). Pochadvskaya letopis. (Noveyshee proizvedenie drevne-volynskoy pismennosti) [Pochaev Chronicle. (The newest work of the ancient Volyn writing)]. Kievskaya Starina [Kyiv Olden], Tom LXI. Kyiv: Tip.G.T.Korchak-Novitskogo. [in Russian].

5. Petrov, N. I. (ed.) (1888). Volyn: Istoricheskie sudby Yugo-Zapadnogo kraya [Volyn: Historical destinies of the South-Western region]. Saint Petersburg: Obshchestvennaya polza. [in Russian].

6. Volynskie eparkhialnye vedomosti (1911). [Volyn Diocesan Gazette (1911)], May, 10. [in Russian].

7. Havryliuk, S. (1997). Diialnist pravoslavnykh tserkovnykh bratstv Volyni u XIX stolitti [Activities of Orthodox church fraternities in Volyn in the XIX century]. Naukovyi visnyk Volynskoho derzhavnoho universytetu im. Lesi Ukrainky: Istoriia [Science Visnik Volynskono State University. Lesi Ukrainka: History], 2. [in Ukrainian].

\footnotetext{
${ }^{1}$ Дело об учреждении «Общества изследователей Вольни. Центральний державний історичний архів України в м. Києві. ф. 442, оп. 627, спр. 302, арк. 14.

${ }^{2}$ Костриця, М., Кондратюк, Р. Краєзнавець М. (1996). Трипольський і його нарис про Житомир.

Житомирський вісник, 19 липня.
} 
8. Devyatisotletie pravoslaviya na Volyni 992-1892 (1892) [The nine hundredth anniversary of Orthodoxy in Volyn 992-1892 (1892)]. Zhytomyr: Tip. Litorg. Ye.P. Lva. [in Russian].

9. Derzhavnyi arkhiv Zhytomyrskoi oblasti. [State Archives of Zhytomyr Region], f.1 op.77. spr. $1782,1799$. f.24.op.1. spr. 242. [in Russian].

10. Zhyliuk, S. (1996). Rosiiska pravoslavna tserkva na Volyni (1793-1917) [Russian Orthodox Church in Volhynia (1793-1917)]. Zhytomyr: Zhurfond. [in Ukrainian].

11. Zhyliuk, S., Boiko, B. (2010). Relihiina polityka tsaryzmu na Volyni (1793-1917) [Religious policy of tsarism in Volhynia (1793-1917)]. Ostroh: Ostrozka akademiia. [in Ukrainian].

12. Zhitetskiy, P. (1876). Opisanie Peresopnitskoy rukopisi XVI st. s prilozhenim teksta Yevangeliya ot Luki, vyderzhek $i z$ drugikh evangelistov $i$ 4-kh stranits snimkov [Description of the Peresopnytsia manuscript of the XVI century. with attached text of the Gospel of Luke, excerpts from other evangelists and 4 pages of photographs]. Kyiv. [in Russian].

13. Zanyatiya professorskogo stipendiata A. Nazarevskogo (1911) [Classes of professor A. Nazarevsky (1911)]. Peretts V. Otchet ob ekskursii seminariya russkoy filologii v Zhitomir 21-26 oktyabrya 1910 goda [Peretts V. Report on the excursion of the seminary of Russian philology to Zhytomyr, October 21-26, 1910]. Kyiv. [in Russian].

14. Kievskaya Starina (1901) [Kyiv Olden (1901)], Tom LXXV. Kyiv: Tip. G. T. Korchak-Novitskogo. [in Russian].

15. Koptiukh, Yu. (2005). Reformy ustroiu Rosiiskoi Pravoslavnoi tserkvy v Pravoberezhnii Ukraini (kinets-XVIII persha polovyna XIX st.) [Reforms of the structure of the Russian Orthodox Church in the Right Bank Ukraine (end - XVIII first half of the XIX century)]: avtoreferat dysertatsiyi na zdobuttya naukovoho stupenyu kandydata istorychnykh nauk [abstract of the dissertation for the degree of Candidate of Historical Sciences]. Kyiv: KNUTSh. [in Ukrainian].

16. Kostrytsia, M., Kondratiuk, R. (1996). Kraieznavets M. Trypolskyi i yoho narys pro Zhytomyr [Local historian M. Trypolsky and his essay on Zhytomyr]. Zhytomyrskyi visnyk [Zhytomyr Herald]. Zhytomyr. [in Ukrainian].

17. Levitskiy, Or. (1896). Arkheologicheskiy sezd v Rige [Archaeological Congress in Riga]. Kievskaya Starina [Kyiv Olden], Tom LV. Kyiv: Tip. G. T. Korchak-Novitskogo. [in Russian].

18. Mishchuk, S. (2009). Zbyrannia ta naukove opysuvannia rukopysno-knyzhkovoi spadshchyny Ukrainy (druha polovyna XIX-30-ti roky XX st.) [Collection and scientific description of the manuscript and book heritage of Ukraine (second half of the XIX - 30s of the XX century)]. Kyiv: Polissia. [in Ukrainian].

19. Tymochko, I. (2010). Orhanizatsiini zasady diialnosti pravoslavnykh bratstv Volynskoi hubernii [Organizational principles of activity of Orthodox fraternities of Volyn province]. Nova pedahohichna dumka [A new pedagogical thought], 3. [in Ukrainian].

20. Tripolskiy, N. (1878). Uniatskiy mitropolit Ipatiy Potsey i ego propovednicheskaya deyatelnost [Uniate Metropolitan Hypatius Potsei and his preaching work]. Kyiv: Tipografiya V. Davidenko. [in Russian].

21. Tripolskiy, N. (1900). Skazanie o chudotvornoy ikone Bozhey Materi Dermanskoy i pesni v chest eya [The legend about the miraculous icon of the Mother of God of Derman and the song in honor of her]. Volynskiy istorikoarkheologicheskiy sbornik [Volyn historical and archaeological collection]. Zhytomyr, 1. [in Russian].

22. Tripolskiy, N. (1900). Dermanskiy arkhimandrit Meletiy Smotritskiy, ego sochineniya i nadgrobnaya nadpis na ego mogile v Dermani [Derman Archimandrite Melety Smotritsky, his writings and a gravestone inscription on his grave in Derman]. Volynskiy istoriko-arkheologicheskiy sbornik [Volyn historical and archaeological collection]. Zhytomyr, 1. [in Russian].

23. Tripolskiy, N. (1900). Dokumenty otnosyashchiesya k drevney istorii pravoslavnogo Pochaevskogo monastyrya na Volyni [Documents relating to the ancient history of the Orthodox Pochaev monastery in Volyn]. Volynskiy istoriko-arkheologicheskiy sbornik [Volyn historical and archaeological collection]. Zhytomyr, 1. [in Russian].

24. Tripolskiy, N. (1900). Volynskoe rukopisnoe Yevangelie XVI st. [Volyn manuscript Gospel of the XVI century]. Volynskiy istoriko-arkheologicheskiy sbornik [Volyn historical and archaeological collection]. Zhytomyr, 2. [in Russian].

25. Tripolskiy, N. (1900). Istoricheskie svedeniya o gorode Zhitomire, Volynskoy gubernii [Historical information about the city of Zhitomir, Volyn province]. Volynskiy istoriko-arkheologicheskiy sbornik [Volyn historical and archaeological collection]. Zhytomyr, 2. [in Russian].

26. Ukazatel trudov Imperatorskogo Pravoslavnogo Palestinskogo Obshchestva 1881-2007 (2009) [Index to the Proceedings of the Imperial Orthodox Palestine Society 1881-2007 (2009)]. Saint Petersburg. [in Russian].

27. Khytrovska, Yu. (2001). Hromadiansko-politychna pozytsiia dukhovenstva Pravoberezhnoi Ukrainy naprykintsi XVIII-seredyni XIX st. (v konteksti tserkovnoi polityky samoderzhavstva) [Civic and political position of the clergy of the Right Bank of Ukraine in the late eighteenth - mid nineteenth century. (in the context of the church policy of the autocracy)]: avtoreferat dysertatsiyi na zdobuttya naukovoho stupenyu kandydata istorychnykh nauk [abstract of the dissertation for the degree of Candidate of Historical Sciences]. Kyiv: In-t filos. im. H. S. Skovorody NAN Ukrainy. [in Ukrainian].

28. Tsentralnyi derzhavnyi istorychnyi arkhiv Ukrainy v m. Kyievi [Central State Historical Archive of Ukraine in Kyiv], F. 442, Op. 627, Spr. 302. [in Russian]. 